\title{
Altered pharmacological effects of adrenergic agonists during hypothermia
}

Erik Sveberg Dietrichs ${ }^{1,2^{*}}$, Georg Sager ${ }^{3}$ and Torkjel Tveita, ${ }^{1,4}$

\begin{abstract}
Rewarming from accidental hypothermia is often complicated by hypothermia-induced cardiac dysfunction, calling for immediate pharmacologic intervention. Studies show that although cardiac pharmacologic support is applied when rewarming these patients, a lack of updated treatment recommendations exist. Mainly due to lack of clinical and experimental data, neither of the international guidelines includes information about pharmacologic cardiac support at temperatures below $30^{\circ} \mathrm{C}$. However, core temperature of accidental hypothermia patients is often reduced below $30^{\circ} \mathrm{C}$. Few human studies exploring effects of adrenergic drugs during hypothermia have been published, and therefore prevailing information is collected from pre-clinical studies. The most prominent finding in these studies is an apparent depressive effect of adrenaline on cardiac function when used in doses which elevate cardiac output during normothermia. Also noradrenaline and isoprenaline largely lacked positive cardiac effects during hypothermia, while dopamine is a more promising drug for supporting cardiac function during rewarming. Data and information from these studies are in support of the prevailing notion; not to use adrenergic drugs at core temperatures below $30^{\circ} \mathrm{C}$.
\end{abstract}

Keywords: Hypothermia, Cooling, Rewarming, Rearming shock, Pharmacology, Cardiovascular dysfunction, Adrenergic drugs, Inotropic, Vasopressor

\section{Background}

Rewarming victims of accidental hypothermia is often complicated by hypothermia-induced cardiac dysfunction. In its fulminant form this condition is described as rewarming shock; an acute heart failure with a progressive fall in cardiac output $(\mathrm{CO})$ where the patient terminates in a sudden and intractable fall in blood pressure [1]. This serious complication to clinical therapy adds to the virtually unchanged low survival rate of accidental hypothermia over the last decades [2,3]. Cardiac supportive therapy has to be instituted during rewarming in an attempt to prevent the imminent cardiovascular collapse. Inotropic drugs, i.e. drugs that enhance force of cardiac contraction [4] could provide such pharmacologic support, but current guidelines do not support this view. Both the American Heart Association and the European Resuscitation Council advise against using

\footnotetext{
* Correspondence: erik.sveberg.dietrichs@uit.no

${ }^{1}$ Anesthesia and Critical Care Research Group, Department of Clinical Medicine, UiT, The Arctic University of Norway, 9037 Tromsø, Norway ${ }^{2}$ Department of Research and Education, Norwegian Air Ambulance Foundation, 1441 Drøbak, Norway

Full list of author information is available at the end of the article
}

drugs like adrenaline below $30{ }^{\circ} \mathrm{C}[5,6]$. Studies investigating patient treatment do however report that inotropic drugs are administered during rewarming in 47$66 \%$ of patients $[7,8]$. Only about $10 \%$ of patients with acute heart failure caused by disease or events other than hypothermia receive the same treatment [9]. This lack of consensus-based guidelines on cardiac inotropic support in hypothermic patients cause confusion, even within the British health care system [10]. Importance of finding optimal treatment for these patients is manifest from that survival is possible after extreme exposure to hypothermia. Case-reports show that early resuscitation enables survival after cooling to $13.7{ }^{\circ} \mathrm{C}$ [11] or cardiac arrest close to $7 \mathrm{~h}$ [12], but mortality rate is still reported at 30\% [2]. Seeking evidence-based pharmacologic treatment options, we have explored the literature for preclinical and clinical studies on use of inotropic drugs during hypothermia and rewarming, with interesting findings. Most studies, including several from our group, focus on adrenergic receptor agonists. The information provided, presents a valuable insight in hypothermiainduced changes in cardiovascular pharmacology, laying 
foundation for development of new treatment strategies and guidelines in a patient group exposed to lethal cardiac complications during rewarming.

\section{Methods}

The aim of this paper was to describe effects of adrenergic agonists during hypothermia. Relevant publications were found through literature search, using PubMed (Medline) and Google Scholar search engines. Experimental and clinical studies included in this narrative review were selected according to their relevance by the authors, who all have a special interest in hypothermia and pharmacology. Reference lists of included papers were studied to discover publications that were not detected through use of search engines. Additional articles describing pathophysiology of hypothermia, treatment guidelines and general knowledge on adrenergic agonists and receptor function, were included for background information.

\section{Adrenergic receptors (Table 1)}

Extracellular binding of adrenergic receptor agonists facilitates initiation of intracellular processes through Gprotein coupled signalling. In 1948, Ahlquist described how the adrenergic receptors are divided into two main groups [13], named $\alpha$ - and $\beta$-receptors. Subgroups have later been identified and separated the receptors into $\alpha_{1-}$ 2 and $\beta_{1-3}$, which have a broad variety of effects, among them hemodynamic. The $\beta_{1}$-receptor is considered most important for inotropic effect and is also more numerous in the mammalian heart (75\%) than $\beta_{2}$ and $\beta_{3}$ [14]. $\beta_{1}$-stimulation enhances heart muscle contraction, increase heart rate and enhance relaxation of myocardial tissue [15]. The effect of $\beta_{1}$-agonists is mediated through stimulation of adenylyl cyclase, which elevates cyclic AMP (cAMP). This activates protein kinase A (PKA), which phosphorylates several proteins. Phosphorylation of sarcolemmal L-type calcium channels gives increased calcium influx, thus enabling contraction, while phosphorylation of cardiac troponin I enhances myocardial relaxation [14]. $\beta_{2}$-stimulation most importantly gives vasodilation due to smooth muscle relaxation [16]. Both $\alpha_{1}$ - and $\alpha_{2}$ - receptors are divided into three subgroups. Stimulation of all $\alpha_{1}$-receptors will in general induce smooth muscle contraction, which gives vasoconstriction [17]. The $\alpha_{2}$-receptor subgroups have differing abilities, among them both vasodilation and vasoconstriction [18]. Cardiovascular effects of adrenergic stimulation are also transmitted through dopamine receptors by direct effect on smooth muscle, giving vasodilation mediated by $D_{1}$-like receptors and indirectly by $D_{2}$-like receptors. Several dopamine receptor subtypes are located in the human heart, namely $D_{1}, D_{2}, D_{4}$, and $D_{5}$ [19], but stimulation of these receptors does not have a pronounced effect on cardiac contractility in rats [20]. Adrenergic receptor agonists have varying affinity for $\beta-, \alpha-$ and dopamine-receptors and their subgroups, explaining their distinct properties.

\section{$\beta_{1}$-receptor function during hypothermia}

As the $\beta_{1}$-receptor is considered most important for providing inotropic effect in normothermic conditions [14] studies on administering adrenergic drugs to ameliorate rewarming shock have also targeted this receptor. In a study from our lab we have reported a 4-fold increase of in vivo cardiac cAMP content during $\beta_{1}$-receptor stimulation at $15{ }^{\circ} \mathrm{C}$, showing that $\beta_{1}$-receptor function is not depressed at low temperatures. This was confirmed by an in vitro 9-fold increase of $\beta_{1}$-receptor sensitivity in isolated rat cardiomyocytes cooled to $15{ }^{\circ} \mathrm{C}$ [21]. Such hypothermia-induced in vitro $\beta_{1}$-receptor super-sensitivity was also described in isolated heart preparations from guinea pig [22, 23] and rabbit hearts at $22{ }^{\circ} \mathrm{C}$ [24]. Results from intact (in vivo) animal experiments studying effects of adrenergic receptor-ligands and -blockers indicate that both $\beta_{1^{-}}$and $\beta_{2}$-receptor function is maintained during cooling to $28-30{ }^{\circ} \mathrm{C}$, but that response to agonist binding is depressed by cooling below $30^{\circ} \mathrm{C}$ [25-27]. The relationship between an apparent increase in $\beta$-receptor sensitivity and decreased inotropic effect below a core temperature

Table 1 Adrenergic receptors

\begin{tabular}{|c|c|c|c|}
\hline & a-receptor & $\beta$-receptor & Dopamine-receptor \\
\hline Subgroups & $a_{1}, a_{2}$ & $\beta_{1}, \beta_{2}, \beta_{3}$ & $D_{1}, D_{2}, D_{3}, D_{4}, D_{5}$ \\
\hline Mechanism of action & G-protein coupled receptors & G-protein coupled receptors & G-protein coupled receptors \\
\hline Molecular effects & $\begin{array}{l}\mathrm{a}_{1}: \text { Activation of PLC, IP3 mediated intracellular } \\
\text { calcium increase } \\
\mathrm{a}_{2} \text { : Decreased CAMP production }\end{array}$ & $\begin{array}{l}\text { Increase of cAMP, protein phosphorylation } \\
\left(\beta_{1}, \beta_{2}, \beta_{3}\right) \text {, intracellular calcium increase }\left(\beta_{1}\right) \\
\text { or decrease }\left(\beta_{2}\right)\end{array}$ & $\begin{array}{l}D_{1}, D_{5}: \text { Increase of } C A M P \\
D_{2}, D_{3}, D_{4}: \text { Decreased } C A M P \\
\text { production }\end{array}$ \\
\hline Hemodynamic effect & $\begin{array}{l}a_{1}: \text { Vasoconstriction } \uparrow \\
a_{2}: \text { Mixed (vasoconstriction or vasodilation) }\end{array}$ & $\begin{array}{l}\beta_{1}: \text { Heart rate } \uparrow, \text { contractility } \uparrow \\
\beta_{2}: \text { Vasodilation } \uparrow\end{array}$ & $\begin{array}{l}D_{1}, D_{5}: \text { Vasodilation } \uparrow \\
D_{2}, D_{3}, D_{4}: \text { Vasoconstriction } \downarrow\end{array}$ \\
\hline Dominant location & $\begin{array}{l}a_{1}: \text { Smooth muscle } \\
a_{2}: \text { Central nervous system }\end{array}$ & $\begin{array}{l}\beta_{1}: \text { Cardiac tissue } \\
\beta_{2}: \text { Smooth muscle } \\
\beta_{3}: \text { Adipose tissue }\end{array}$ & $\begin{array}{l}D_{1}, D_{2}, D_{3}, D_{4}, D_{5}: \\
\text { Central nervous system }\end{array}$ \\
\hline
\end{tabular}


of $30{ }^{\circ} \mathrm{C}$ is uncertain. Mann [28] found excessive cAMP levels, seen during $\beta_{1}$-receptor stimulation in hypothermic rats [21], to be cardiotoxic, through initiating unphysiological increase of cytosolic calcium levels, mediated by increased phosphorylation of L-type calcium channels [28]. Hypothermia-induced calcium overload is also known to take place in response to prolonged hypothermia in rats per se $[29,30]$ and an additional increased calcium load in response to a pharmacologic stimulation might explain lacking effect of $\beta_{1}$-agonists during hypothermia. Another observed effect of temperature reduction in rats is reduced myocardial calcium sensitivity due to hypothermia-induced elevation of PKA-mediated phosphorylation of Ser 23/24 at cardiac troponin I [31]. Increased levels of cAMP will increase such PKA-mediated Ser 23/24 phosphorylation and give a negative inotropic effect. Such phosphorylation will also enhance cardiac relaxation [32], which is normalized during rewarming from hypothermia as diastolic function is restored [33]. Thus, favorable or harmful effects of $\beta_{1}$-agonists administration in hypothermic subjects appears associated to inotropic rather than lusitropic properties, as hypothermia-induced cardiac dysfunction is an isolated impairment of systolic function [1].

The aforementioned studies do however show differences in species and experimental conditions and use several $\beta_{1}$-receptor agonists with varying properties, including $\alpha$-receptor agonism that promotes vasoconstriction. A resulting increase of systemic vascular resistance (SVR) cause a pronounced negative effect on cardiac function in rats during hypothermia [21, 27, 34, 35]. For assessment of clinical properties of these drugs, it is therefore necessary to evaluate their individual pharmacologic effects when used during hypothermia.

\section{Adrenergic receptor agonists (Table 2, Fig. 1) Adrenaline}

Adrenaline will enhance cardiac contraction and heart rate and either decrease (low-dose) or increase (highdose) SVR in normothermic conditions [36], conducted by loss of $\beta$-adrenergic selectivity at low doses with increasing $\alpha$-stimulation at higher doses.

Adrenaline during hypothermia Pharmacodynamic effects of adrenaline do not seem to be independent of temperature changes. Rubinstein found that doses inducing vasodilation in normothermic dogs would give increased SVR during hypothermia and stated that the inotropic effect of adrenaline is reduced at $25^{\circ} \mathrm{C}$ [37]. A similar study on rats conducted in our lab, showed that a high dose of adrenaline $(1.25 \mu \mathrm{g} / \mathrm{min})$ increased stroke volume (SV) and CO in normothermic animals. When an equal dose was administered during rewarming from $15{ }^{\circ} \mathrm{C}$ however, SV and CO were unaffected. In contrast, a low dose $(0.125 \mu \mathrm{g} / \mathrm{min})$ adrenaline, which induced vasodilation during normothermic conditions, failed to reduce SVR or mean arterial pressure (MAP) during rewarming, but led to an elevated $\mathrm{CO}$ [34]. The positive effect of low-dose adrenaline during hypothermia has also been reported from experiments using dogs [38]. We found the same dose-response relationship during cooling, where $0.125 \mu \mathrm{g} / \mathrm{min}$ but not $1.25 \mu \mathrm{g} / \mathrm{min}$ adrenaline gave positive cardiac effects during cooling to $28{ }^{\circ} \mathrm{C}$. After rewarming, only rats that had received saline during cooling showed pre-hypothermic hemodynamic responses to adrenaline [27]. An additional study on rats from our lab showed that $1 \mu \mathrm{g} / \mathrm{min}$ of adrenaline given during cooling caused a maintained depression of cardiac function during rewarming [35]. These results indicate that hypothermia has a severe impact on cardiac inotropic effects mediated by the $\beta_{1}$-receptor pathway, as $\beta_{1}$-adrenergic stimulation during hypothermia also has a negative impact on inotropic effect of $\beta_{1}$-agonists after rewarming. The same phenomenon is also observed in a feline model of hypothermia and rewarming $[39,40]$. From a combined in vitro and in vivo study in our lab, we showed that this hypothermiainduced reduction of inotropic effect via $\beta_{1}$-receptor stimulation is seen in the presence of in vivo and in vitro $\beta_{1}$-receptor super-sensitivity. Both increased $\beta_{1}$ receptor binding and elevated cAMP levels were seen during administration of $\beta_{1}$-receptor ligands in hypothermic conditions, as compared to normothermia. This study indicates that the detrimental effects of adrenaline during hypothermia is a consequence of adrenaline-induced increase in SVR via peripheral vascular $\alpha$-receptor stimulation [21]. Failure of low doses of adrenaline to reduce MAP during hypothermia [34], further implies the presence of increased $\alpha$-receptor agonism, or reduced effect of $\beta_{2}$-receptor agonism in hypothermia.

Altogether, the present hypothermia-induced alteration of pharmacodynamic effects and an expected narrowed therapeutic window of adrenaline, advocate against the use of this drug during hypothermia. This assumptions gain support by data from in vitro experiments. In isolated rat hearts, both $\mathrm{SV}$ and $\mathrm{CO}$ were depressed by adrenaline at $28{ }^{\circ} \mathrm{C}$ [41], while at $12{ }^{\circ} \mathrm{C}$ positive inotropic effects were absent [42]. Interestingly, Schiffmann et al. demonstrated that in normothermic rat hearts, the presence of additionally added calcium would potentiate the inotropic effects of adrenaline. In the hypothermic heart however, increased calcium concentrations [41] mediated a depressive effect of adrenaline on SV and CO. Thus, the negative effects of adrenaline at low temperatures could be a consequence of hypothermia-induced calcium overload, reported in vitro [43], as well as in vivo [29, 30]. 
Table $2 \beta_{1}$-receptor agonists

\begin{tabular}{|c|c|c|c|c|c|}
\hline & Adrenaline & Noradrenaline & Isoprenaline & Dobutamine & Dopamine \\
\hline Species & Rat, dog & Cat, dog, & Rat, dog, rabbit, guinea pig & Dog, pig, rabbit, guinea pig & Dog, pig \\
\hline Dosage (in vivo) & $0.4 \mu \mathrm{g} / \mathrm{kg} / \mathrm{min}-4.2 \mu \mathrm{g} / \mathrm{kg} / \mathrm{min}$ & $0.2 \mu \mathrm{g} / \mathrm{kg} / \mathrm{min}-5.0 \mu \mathrm{g} / \mathrm{kg} / \mathrm{min}$ & $5.7 \mathrm{ng} / \mathrm{kg} / \mathrm{min}-1$ $\mu \mathrm{g} / \mathrm{kg}$ (bolus) & $2.0 \mu \mathrm{g} / \mathrm{kg} / \mathrm{min}-30 \mu \mathrm{g} / \mathrm{kg} / \mathrm{min}$ & $2.0 \mu \mathrm{g} / \mathrm{kg} / \mathrm{min}-30 \mu \mathrm{g} / \mathrm{kg} / \mathrm{min}$ \\
\hline Administration & $\begin{array}{l}\text { i.v. (in vivo studies), Retrograd } \\
\text { coronary perfusion } \\
\text { (in vitro studies) }\end{array}$ & i.v. (in vivo studies) & $\begin{array}{l}\text { i.v. (in vivo studies), Retrograd } \\
\text { coronary perfusion or in } \\
\text { preparation solution } \\
\text { (in vitro studies) }\end{array}$ & $\begin{array}{l}\text { i.v. (in vivo studies), Retrograd } \\
\text { coronary perfusion or in } \\
\text { preparation solution } \\
\text { (in vitro studies) }\end{array}$ & i.v. (in vivo studies) \\
\hline Target temperature & $12^{\circ} \mathrm{C}-28^{\circ} \mathrm{C}$ & $28^{\circ} \mathrm{C}-30^{\circ} \mathrm{C}$ & $20^{\circ} \mathrm{C}-28^{\circ} \mathrm{C}$ & $22^{\circ} \mathrm{C}-31^{\circ} \mathrm{C}$ & $25^{\circ} \mathrm{C}-30^{\circ} \mathrm{C}$ \\
\hline Cardiac effect (hypothermia) & $\begin{array}{l}\text { Elevated CO (low dose) } \\
\text { [27, 34, 38]. Depressed CO } \\
\text { (high dose) }[21,27,34,35,37] . \\
\text { Negative inotropic effects } \\
\text { (in vitro) }[41,42] .\end{array}$ & $\begin{array}{l}\text { Increased contractile force } \\
{[26,45] \text {. Depressed CO [40]. }}\end{array}$ & $\begin{array}{l}\text { No effect on CO }[50,51] \text {. } \\
\text { Negative or depressed } \\
\text { inotropic effect (in vitro) } \\
{[52,53] \text {. }} \\
\text { Positive inotropic effects } \\
\text { (in vitro) }[22,24,54] \text {. }\end{array}$ & $\begin{array}{l}\text { Elevated CO [38, 57]. Increased } \\
\text { contraction velocity (in vitro) } \\
\text { [24]. } \\
\text { Reduced or depressed } \\
\text { inotropic effect (in vitro) [56]. }\end{array}$ & $\begin{array}{l}\text { Elevated CO or positive } \\
\text { inotropic effects }[57,61,63] \text {. } \\
\text { No effect on CO }[62,63] \text {. }\end{array}$ \\
\hline
\end{tabular}




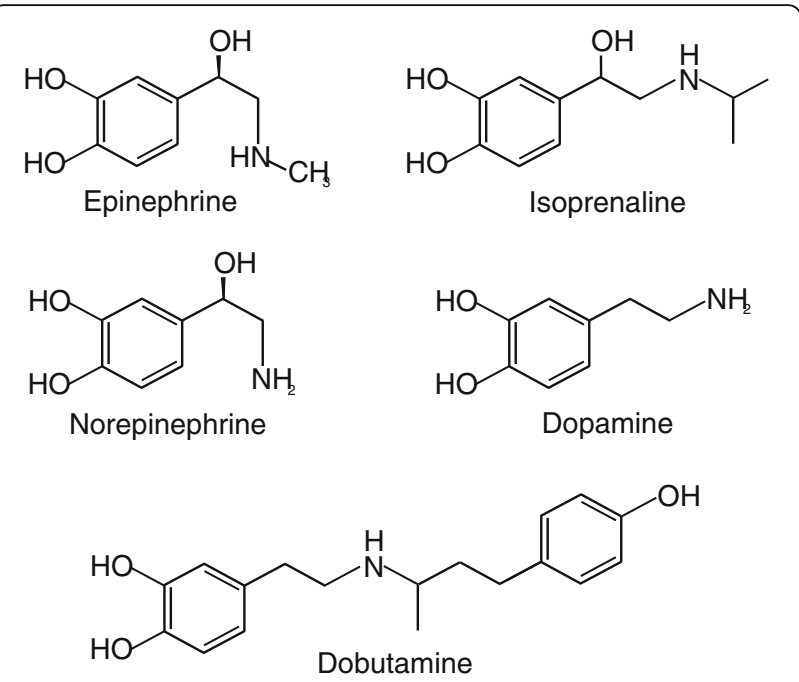

Fig. 1 Molecular structure of adrenaline, noradrenaline, isoprenaline, dopamine and dobutamine

\section{Noradrenaline}

Noradrenaline has high affinity for $\alpha$-receptors in concert with $\beta_{1}$-receptor affinity. Infusion of noradrenaline therefore leads both to vasoconstriction of arterioles and a positive inotropic effect [44].

Noradrenaline during hypothermia Cotten et al. demonstrated positive inotropic effect of noradrenaline in both normothermic controls and hypothermic $\left(30{ }^{\circ} \mathrm{C}\right)$ dogs [26]. They further described that although this effect was positive, the inotropic effect of noradrenaline was reduced by hypothermia [45]. In cats subjected to moderate hypothermia and rewarming, noradrenaline had a negative effect on $\mathrm{CO}$ during hypothermia. The ability of noradrenaline to induce vasoconstriction did however appear intact during cooling, with consistent dose-related increase in MAP [40]. Intact $\alpha$-receptor function is also apparent during noradrenaline infusion in humans cooled on cardiopulmonary bypass to 28$32{ }^{\circ} \mathrm{C}$. In these patients MAP increased significantly with noradrenaline [46]. This can be explained by intact $\alpha_{1-}$ receptor function during a wide range of temperatures, as demonstrated in sheep arteries where vascular response to noradrenaline abolished first when cooling to $5{ }^{\circ} \mathrm{C}$ [47]. The sensitivity of $\alpha$-receptors was even found to be increased in human skin artery preparations cooled to $24{ }^{\circ} \mathrm{C}[48]$.

\section{Isoprenaline}

Isoprenaline is a non-selective $\beta$-receptor agonist, lacking $\alpha$-agonist effect. On this background studies looking exclusively at $\beta$-receptor stimulation often use isoprenaline as a model drug. During normothermic conditions, isoprenaline will increase $\mathrm{CO}$ and decrease SVR through $\beta_{1}$ - and $\beta_{2}$-receptor stimulation [49].

Isoprenaline during hypothermia Conflicting results exist of pharmacologic effects of isoprenaline at low temperatures, especially when comparing results obtained from in vitro interventional studies of cardiac tissue from different species. Lauri et al. studied in vivo hemodynamic effects of isoprenaline before, during and after severe hypothermia $\left(25^{\circ} \mathrm{C}\right)$ in dogs. Isoprenaline had no positive inotropic effect during hypothermia, but a significant decrease in SVR indicated at least partly intact $\beta_{2}$-receptor response to stimulation [50], also seen in man at $28-32{ }^{\circ} \mathrm{C}$ [46]. Inotropic effects of increasing isoprenaline doses have been investigated in our intact rat model [51] at normothermia and during cooling to $24{ }^{\circ} \mathrm{C}$. We reported that the dose-related positive inotropic response (increase in $\mathrm{SV}$ and $\mathrm{CO}$ ) to isoprenaline at $37{ }^{\circ} \mathrm{C}$ were lost during cooling to $24{ }^{\circ} \mathrm{C}$ except for the highest dose $(20 \mathrm{ng} / \mathrm{min})$. This alteration in response to $\beta$-receptor stimulation also remained after rewarming as only the highest dose of isoprenaline managed to elevate SV above baseline [51]. In vitro studies have shown depressed $\beta_{1}$-mediated inotropic effect of isoprenaline in rat left atrial preparations at 28 and $20{ }^{\circ} \mathrm{C}$, compared to at $35{ }^{\circ} \mathrm{C}$ [52]. This finding finds support in another study reporting reduced inotropic response to both isoprenaline and adrenaline in hypothermic rabbit atria at $23{ }^{\circ} \mathrm{C}$ [53]. In contrast, in isolated guinea pig hearts cooled to $27{ }^{\circ} \mathrm{C}$ isoprenaline still increased the contractility parameter $\mathrm{LV} \mathrm{dp} / \mathrm{dt}_{\max }$, this was accompanied by a similar increase in heart rate, also mediated by $\beta_{1}$-receptor stimulation [54]. Further, an experiment on isolated atria from guinea pig showed increased inotropic effects of isoprenaline at $25{ }^{\circ} \mathrm{C}$ [22]. Sustained ability of adrenaline and isoprenaline to increase contraction amplitude and rate has also been reported when cooling rabbit hearts to $22{ }^{\circ} \mathrm{C}$ [24].

\section{Dobutamine}

Dobutamine predominantly binds to $\beta_{1}$-receptors and has a weak effect on $\beta_{2}$ - and $\alpha$-receptors. Thus, administering dobutamine in normothermic conditions elevates $\mathrm{CO}[55]$.

Dobutamine during hypothermia The inotropic effects of dobutamine shows temperature dependency when tested in in vitro guinea pig trabecula. Rieg et al. [56] therefore concluded that elevating cAMP through $\beta_{1}$-receptor stimulation for providing inotropic support in hypothermic hearts is not an optimal strategy. In isolated rabbit hearts however, dobutamine infusion increased contraction velocity at $22{ }^{\circ} \mathrm{C}$ [24]. Increased cardiac output was also observed in response to 
dobutamine infusion during hypothermia $\left(30{ }^{\circ} \mathrm{C}\right)$ in pigs [57]. Administering dobutamine in an intact dog model during reperfusion following $60 \mathrm{~min}$ global ischemia at $28{ }^{\circ} \mathrm{C}$ also showed promising cardiac effects, with increased SV during rewarming using cardio-pulmonary bypass [38].

\section{Dopamine}

Like adrenaline, noradrenaline, isoprenaline and dobutamine, dopamine is a catecholamine, giving dosedependent stimulation of $\alpha$ - and $\beta$-receptors and giving a dose-dependent positive inotropic effect in normothermia [58]. Different from selective adrenergic agonists, dopamine also exerts its inotropic and vasoactive effects through stimulation of dopamine receptors [59].

Dopamine during hypothermia The use of dopamine as a vasopressor is recommended in the Up To Date accidental hypothermia guidelines [60]. This is supported by a better cardiovascular recovery in dopamine-treated dogs, after core cooling to $25{ }^{\circ} \mathrm{C}$ and subsequent rewarming [61]. Likewise, positive inotropic effects of dopamine were found in pigs core cooled to $30{ }^{\circ} \mathrm{C}$ [57]. However, in pigs surface cooled to $32{ }^{\circ} \mathrm{C}$ [62] and $25^{\circ} \mathrm{C}$ [63] dopamine did not elevate $\mathrm{CO}$. In the latter study, which was conducted in our lab [63], dopamine infusion at $25{ }^{\circ} \mathrm{C}$ gave a four-fold increase in plasma concentration compared to normothermia. In difference from other $\beta$-adrenergic drugs, cardiovascular responses of dopamine were restored during rewarming to $30^{\circ} \mathrm{C}$ [63]. It is therefore apparent from different animal models that dopamine supports cardiac function during rewarming, but it is uncertain whether these positive effects are present during hypothermia below $30{ }^{\circ} \mathrm{C}$. Based on these findings, dopamine is the preferred drug for giving cardiac support during rewarming in the Northern-Norwegian guidelines for accidental hypothermia [64].

\section{Conclusion}

\section{Pharmacodynamics}

A lack of human studies evaluating cardiovascular effects of adrenergic drugs during hypothermia exists [65]. In the meantime such information can be collected from preclinical experimental studies. This information provide important insight on the effects of pharmacologic interventions already applied in the hypothermic patient. It is apparent that inotropic response to $\beta$-adrenergic stimulation seems to be depressed during severe hypothermia. This response is also depressed after rewarming in animals that have received such drugs during hypothermia [51]. In hypothermic animals, adrenaline increases SVR [21]. Studies on dobutamine administration indicates a positive effect, but these studies are carried out at temperatures around $30{ }^{\circ} \mathrm{C}[38,57]$.
Advice of the current guidelines, not to use adrenergic drugs like adrenaline below $30{ }^{\circ} \mathrm{C}$ is supported by these preclinical observations, but recommendations for inotropic support in severe accidental hypothermic $\left(>30{ }^{\circ} \mathrm{C}\right)$ patients are needed. Dopamine does not seem to have the same detrimental effects on cardiovascular function in severe accidental hypothermia as adrenaline, even in high plasma concentrations [63], but lack effect before patients are rewarmed to higher temperatures.

\section{Pharmacokinetics}

Knowledge about pharmacokinetic effects of adrenergic drugs during hypothermia is limited. However, all pharmacokinetic processes are temperature-dependent; including absorption, distribution and elimination (metabolism and excretion). In general, lowered temperatures slow all these processes down. The time to reach distribution equilibrium will be lengthened and metabolism in the liver and active excretion in the kidneys reduced. Thus half-life $\left(\mathrm{T}_{1 / 2}\right)$ of active substances is increased at low temperatures [66]. In humans, it is known that the cytochrome P450 enzyme system is affected by hypothermia. Tortorici [67] found that this resulted in a $7-22 \%$ reduced clearance per degree below $37{ }^{\circ} \mathrm{C}$ of opiates, barbiturates, benzodiazepines and neuromuscular blockers. Hypothermia does also induce changes in pharmacokinetics of adrenergic drugs. Reduced catechol-O-methyl transferase activity has therefore been suggested to explain a hypothermia-induced hypersensitivity to $\beta$-adrenoceptor agonists [24]. Increased $T_{1 / 2}$ of adrenaline might therefore have contributed to elevated stimulation of $\beta$-adrenoceptors in a recent study reporting increased cAMP levels during 5 min adrenaline administration in hypothermia [21], as the normothermic $\mathrm{T}_{1 / 2}$ of adrenaline is $2 \mathrm{~min}$ [68]. Reduced enzymatic breakdown of cAMP through reduced phosphodiesterase 3 activity, or reduced extracellular release of cAMP as observed in cold fibroblasts [69], might also have boosted adrenaline-mediated cAMP increase in hypothermic hearts [21]. Hypothermia-induced increase in $T_{1 / 2}$ is apparent for other catecholamines. At $25{ }^{\circ} \mathrm{C}$ in anesthetised pigs, we found that dopamine infusion yielded plasma concentrations 4 times higher than during normothermia. The half-life of dopamine was doubled at this temperature and returned to normothermic values first at $35{ }^{\circ} \mathrm{C}$ during rewarming [63]. The high concentrations of dopamine were however not associated with any negative hemodynamic effects.

Apart from temperature-dependent pharmacologic changes in ligand-receptor kinetics, changes in temperature also exert significant alterations in other determinants of cardiac function, which may limit the expected pharmacologic effects achieved at normothermia. During cooling, studies on isolated papillary muscle 
show a positive inotropic effect of hypothermia per se [70]. In the intact pig however, cooling induce a reduction of cardiac contractile function and SV [33]. Lewis and colleagues showed that the inotropic effect of increasing heart rate during normothermic conditions in man, is lost at a core temperature of $33{ }^{\circ} \mathrm{C}$ [71], independent of pharmacologic interventions. Consequently, hypothermia-induced changes in physiology, not related to ligand-receptor kinetics, could also be involved in altered pharmacodynamics of $\beta$-adrenoceptor agonists during hypothermic conditions. Important determinants of blood flow, like blood viscosity, are affected already at moderate hypothermia [72]. Thus, lack of ability of the cold blood to increase flow may be part of the challenging task to provide positive inotropic, pharmacologic support during hypothermia. The apparent depressed function of $\beta_{1}$-receptor agonists to provide inotropic effect in vivo below $30{ }^{\circ} \mathrm{C}$, might therefore be multifactorial. Updated guidelines on treatment of hypothermic patients depend on further studies exploring physiological effects of hypothermia and rewarming, as well as broader knowledge on the hypothermia-induced changes on pharmacodynamic and pharmacokinetic effects of drugs applied in clinical practice.

\section{Clinical implications}

Findings in the reviewed literature indicate that negative or lacking effects of adrenergic drugs during hypothermia appears to be of multifactorial origin. Our findings from a majority of pre-clinical studies therefore advocate that drugs providing adrenergic receptor agonism should be used carefully during hypothermia and rewarming. Such information is highly relevant in the clinical setting. Reports show that pharmacological interventions are being used to provide cardiovascular support in a large proportion of patients during rewarming from accidental hypothermia [7, 8]. Hypothermia is also used as a therapeutic measure. Comatose survivors of cardiac arrest are often cooled to temperatures between $32-36{ }^{\circ} \mathrm{C}$ for cerebral protection [73]. More than 50\% of this patient group are in need of inotropic support to facilitate adequate circulation [74]. Cooling and rewarming of patients down to, and occasionally below $20^{\circ} \mathrm{C}$ is also used for cerebral protection during procedures like aortic arch surgery [73]. Providing optimal pharmacological, cardiovascular support in hypothermic patients therefore seems essential, both in therapeutic hypothermia, and when aiming to improve a high mortality rate associated with accidental hypothermia [2]. In pigs, dopamine appear a safe way to provide inotropic support, but lack effect at lower temperatures. Further, experimental studies have explored effects of inotropic pathways like PDE3 inhibition and calcium sensitizing, drugs that avoid the G-protein coupled adrenergic receptors. These experiments show promising results [75-79] on cardiovascular function, both during cooling and rewarming. However, information from such pre-clinical studies should be interpreted with care, when translated to a clinical, human setting. Aiming to provide better treatment, we call for further studies on physiology, therapeutic interventions and careful evaluation of inotropic drugs, used in hypothermic patients.

\section{Abbreviations \\ CAMP: Cyclic AMP; CO: Cardiac output; MAP: Mean arterial pressure; PKA: Protein kinase A; SV: Stroke volume; SVR: Systemic vascular resistance; $\mathrm{T}_{1 / 2}$ : Half-life}

\section{Acknowledgements}

Not applicable.

Funding

The authors' salaries were funded by their respective affiliations.

Availability of data and materials

Not applicable. All data and material are available in the referenced articles.

Authors' contributions

Wrote, or contributed to write the manuscript: ESD, GS and TT. All authors have read and approved the final version of the manuscript.

Competing interests

The authors declare that they have no competing interests.

Consent for publication

Not applicable.

Ethics approval and consent to participate

Not applicable.

\section{Author details}

${ }^{1}$ Anesthesia and Critical Care Research Group, Department of Clinical Medicine, UiT, The Arctic University of Norway, 9037 Tromsø, Norway.

${ }^{2}$ Department of Research and Education, Norwegian Air Ambulance

Foundation, 1441 Drøbak, Norway. ${ }^{3}$ Experimental and Clinical Pharmacology, Department of medical biology, UiT, The Arctic University of Norway, 9037

Tromsø, Norway. ${ }^{4}$ Division of Surgical Medicine and Intensive Care, University Hospital of North Norway, 9038 Tromsø, Norway.

Received: 6 October 2016 Accepted: 29 November 2016

Published online: 05 December 2016

\section{References}

1. Tveita T. Rewarming from hypothermia. Newer aspects on the pathophysiology of rewarming shock. Int J Circumpolar Health. 2000;59:260-6

2. van der Ploeg G-J, Goslings JC, Walpoth BH, Bierens JJLM. Accidental hypothermia: rewarming treatments, complications and outcomes from one university medical centre. Resuscitation. 2010;81:1550-5.

3. Maclean D, Maclean E-SD, Emslie-Smith. Accidental hypothermia. 1977.

4. Furnival CM, Linden RJ, Snow HM. Inotropic changes in the left ventricle: the effect of changes in heart rate, aortic pressure and end-diastolic pressure. J Physiol. 1970;211:359-87.

5. Vanden Hoek TL, Morrison LJ, Shuster M, Donnino M, Sinz E, Lavonas EJ, et al. Part 12: cardiac arrest in special situations: 2010 American Heart Association Guidelines for cardiopulmonary resuscitation and emergency cardiovascular care. Circulation. 2010:122:S829-61.

6. Truhlář A, Deakin CD, Soar J, Khalifa GEA, Alfonzo A, Bierens JJLM, et al. European resuscitation council guidelines for resuscitation 2015: section 4 Cardiac arrest in special circumstances. Resuscitation. 2015;95:148-201.

7. Kornberger $\mathrm{E}, \mathrm{Schwarz} \mathrm{B}$, Lindner KH, Mair P. Forced air surface rewarming in patients with severe accidental hypothermia. Resuscitation. 1999;41:105-11. 
8. Vassal T, Benoit-Gonin B, Carrat F, Guidet B, Maury E, Offenstadt G. Severe accidental hypothermia treated in an ICU: prognosis and outcome. Chest. 2001;120:1998-2003

9. Abraham WT, Adams KF, Fonarow GC, Costanzo MR, Berkowitz RL, LeJemtel TH, et al. In-hospital mortality in patients with acute decompensated heart failure requiring intravenous vasoactive medications: an analysis from the Acute Decompensated Heart Failure National Registry (ADHERE). J Am Coll Cardiol. 2005;46:57-64.

10. Saraswatula A, Cornwell L, Latifi S. Inconsistencies in the guidelines: use of adrenaline in paediatric cardiac arrest with hypothermia. Resuscitation. 2008;77:142-3.

11. Gilbert M, Busund R, Skagseth A, Nilsen PA, Solbø JP. Resuscitation from accidental hypothermia of 13.7 degrees $C$ with circulatory arrest. Lancet. 2000;355:375-6

12. Kosinski S, Darocha T, Jarosz A, Migiel L, Zelias A, Marcinkowski W, et al. The longest persisting ventricular fibrillation with an excellent outcome - 6 h 45 min cardiac arrest. Resuscitation. 2016

13. Ahlquist RP. A study of the adrenotropic receptors. Am J Physiol. 1948;153:586-600

14. Bers DM. Excitation-Contraction Coupling and Cardiac Contractile Force. Dordrecht: Springer; 2001. https://books.google.no/books?id=0p8AqZP7D5UC \&pg=PA203\&dq=Excitation-Contraction+Coupling+and+Cardiac+Contractile +Force+publisher+location\&hl=no\&sa=X\&ved=0ahUKEwjp9tid5tPQA hUoYZoKHZKPB5gQ6AEIJDAB\#v=onepage\&q=Excitation-Contraction\% 20Coupling\%20and\%20Cardiac\%20Contractile\%20Force\%20publisher\% 20location\&f=false.

15. Rohrer DK, Desai KH, Jasper JR, Stevens ME, Regula DP, Barsh GS, et al. Targeted disruption of the mouse beta1-adrenergic receptor gene: developmental and cardiovascular effects. Proc Natl Acad Sci U S A. 1996;93:7375-80.

16. Chruscinski AJ, Rohrer DK, Schauble E, Desai KH, Bernstein D, Kobilka BK. Targeted disruption of the beta2 adrenergic receptor gene. J Biol Chem. 1999:274:16694-700.

17. Woodman OL, Vatner SF. Coronary vasoconstriction mediated by alpha 1and alpha 2-adrenoceptors in conscious dogs. Am J Physiol. 1987;253:H388-93.

18. Kable JW, Murrin LC, Bylund DB. In vivo gene modification elucidates subtype-specific functions of alpha(2)-adrenergic receptors. J Pharmacol Exp Ther. 2000;293:1-7.

19. Cavallotti C, Mancone M, Bruzzone P, Sabbatini M, Mignini F. Dopamine receptor subtypes in the native human heart. Heart Vessels. 2010;25:432-7.

20. Polakowski JS, Segreti JA, Cox BF, Hsieh GC, Kolasa T, Moreland RB, et al. Effects of selective dopamine receptor subtype agonists on cardiac contractility and regional haemodynamics in rats. Clin Exp Pharmacol Physiol. 2004;31:837-41.

21. Dietrichs ES, Schanche T, Kondratiev T, Gaustad SE, Sager G, Tveita T. Negative inotropic effects of epinephrine in the presence of increased $\beta$-adrenoceptor sensitivity during hypothermia in a rat model. Cryobiology. 2015;70:9-16.

22. Chess-Williams RG, Broadley KJ, Duncan C. A fundamental temperaturedependent difference between beta-adrenoceptor agonists and antagonists. Life Sci. 1984;35:1091-9.

23. Williams RG, Broadley KJ. Responses mediated via beta 1, but not beta 2-adrenoceptors, exhibit hypothermia-induced supersensitivity. Life Sci. 1982;31:2977-83.

24. Riishede L, Nielsen-Kudsk F. Myocardial effects of adrenaline, isoprenaline and dobutamine at hypothermic conditions. Pharmacol Toxicol. 1990;66:354-60.

25. Melnikov AL, Løkebø JE, Helgesen KG, Lathrop DA. Influence of hypothermia on the cardiac effects of propranolol observed in isolated rat atria. Gen Pharmacol. 1997;28:55-9.

26. Cotten MV, Logan ME, Moore Jl. Relationships among cardiac inotropic responses to norepinephrine and cardiac and blood concentrations of H3norepinephrine during hypothermia. J Pharmacol Exp Ther. 1967;155:231-41.

27. Tveita T, Sieck GC. The physiologic responses to epinephrine during cooling and after rewarming in vivo. Crit Care. 2011;15:R225.

28. Mann DL, Kent RL, Parsons B, Cooper G. Adrenergic effects on the biology of the adult mammalian cardiocyte. Circulation. 1992;85:790-804.

29. Kondratiev TV, Wold RM, Aasum E, Tveita T. Myocardial mechanical dysfunction and calcium overload following rewarming from experimental hypothermia in vivo. Cryobiology. 2008;56:15-21.

30. Wold RM, Kondratiev T, Tveita T. Myocardial calcium overload during graded hypothermia and after rewarming in an in vivo rat model. Acta Physiol. 2013;207:460-9.
31. Han YS, Tveita T, Prakash YS, Sieck GC. Mechanisms underlying hypothermia-induced cardiac contractile dysfunction. Am J Physiol Heart Circ Physiol. 2010;298:H890-7.

32. Li L, Desantiago J, Chu G, Kranias EG, Bers DM. Phosphorylation of phospholamban and troponin I in beta-adrenergic-induced acceleration of cardiac relaxation. Am J Physiol Heart Circ Physiol. 2000;278:H769-79.

33. Filseth OM, How O-J, Kondratiev T, Gamst TM, Tveita T. Post-hypothermic cardiac left ventricular systolic dysfunction after rewarming in an intact pig model. Crit Care. 2010;14:R211.

34. Kondratiev TV, Myhre ESP, Simonsen $\varnothing$, Nymark T-B, Tveita T. Cardiovascular effects of epinephrine during rewarming from hypothermia in an intact animal model. J Appl Physiol. 2006;100:457-64.

35. Kondratiev TV, Tveita T. Effects of sympathetic stimulation during cooling on hypothermic as well as posthypothermic hemodynamic function. Can J Physiol Pharmacol. 2006;84:985-91.

36. Rang HP, Dale MM, Flower RJ, Ritter JM, Henderson G. Rang \& Dale's pharmacology. 7th ed. 2011.

37. Rubinstein EH. Vascular responses to adrenaline, noradrenaline and angiotensin in hypothermic dogs. Acta Physiol Lat Am. 1961;11:30-7.

38. Sunamori M, Ozeki M, Okamura T, Amano J, Suzuki A. Effects of catecholamines on myocardial viability in early reperfusion following hypothermic global ischemia in dogs-comparison between epinephrine and dobutamine. Jpn J Surg. 1985;15:463-70.

39. Weiss SJ, Muniz A, Ernst AA, Lippton HL, Nick TG. The effect of prior hypothermia on the physiological response to norepinephrine. Resuscitation. 2000;45:201-7.

40. Weiss SJ, Muniz A, Ernst AA, Lippton HL. The physiological response to norepinephrine during hypothermia and rewarming. Resuscitation. 1998:39:189-95.

41. Schiffmann H, Gleiss J, von Hirscheydt A, Schröder T, Kahles H, Hellige G. Effects of epinephrine on the myocardial performance and haemodynamics of the isolated rat heart during moderate hypothermia-importance of calcium homeostasis. Resuscitation. 2001:50:309-17.

42. Nayler WG, Wright JE, Howells J. Effect of Epinephrine on the Mechanical and Phosphorylase Activity of Normo-and Hypothermic Hearts. Circ Res. 1963;13:199-206.

43. Aasum E. Stimulation of carbohydrate metabolism reduces hypothermiainduced calcium load in fatty acid-perfused rat hearts. J Mol Cell Cardiol. 1997;29:527-34

44. Kirkendol PL, Woodbury RA. Hemodynamic effects of infused norepinephrine in dogs on cardiopulmonary bypass. J Pharmacol Exp Ther. 1972;181:369-76.

45. Moore Jl, Cotten MV. Influence of norepinephrine and ouabain of cardiac muscle mechanics during hypothermia. J Pharmacol Exp Ther. 1967;155: 250-8.

46. Baraka A, Haroun S, Baroody M, Nawfal M, Sibai A. Action of adrenergic agonists on resistance $v$ capacitance vessels during cardiopulmonary bypass. J Cardiothorac Anesth. 1989;3:193-5

47. Keatinge WR. Mechanism of adrenergic stimulation of mammalian arteries and its failure at low temperatures. J Physiol. 1964;174:184-205.

48. Gómez B, Borbujo J, García-Villalón AL, Nava-Hernández E, Valle J, García JL, et al. Alpha 1- and alpha 2-adrenergic response in human isolated skin arteries during cooling. Gen Pharmacol. 1991:22:341-6.

49. Beregovich J, Reicher-Reiss H, Grishman A. Haemodynamic effects of isoprenaline in acute myocardial infarction. Br Heart J. 1972:34:705.

50. Lauri T. Cardiovascular responses to beta-stimulation with isoproterenol in deep hypothermia. J Appl Physiol. 1996;81:573-7.

51. Han Y-S, Tveita T, Kondratiev TV, Prakash YS, Sieck GC. Changes in cardiovascular $\beta$-adrenoceptor responses during hypothermia. Cryobiology. 2008;57:246-50

52. Melnikov AL, Løkebø JE, Lathrop DA, Helgesen KG. Alteration of the cardiac effects of isoproterenol and propranolol by hypothermia in isolated rat atrium. Gen Pharmacol. 1996;27:665-8.

53. Omar SA, Hammad D, Varma S. Reduced beta adrenergic responsiveness in isolated rabbit atria during hypothermia. Indian J Physiol Pharmacol. 1979; 23:199-203.

54. Nakae Y, Fujita S, Namiki A. Isoproterenol enhances myofilament $\mathrm{Ca}(2+)$ sensitivity during hypothermia in isolated guinea pig beating hearts. Anesth Analg. 2001;93:846-52

55. Stoner JD, Bolen JL, Harrison DC. Comparison of dobutamine and dopamine in treatment of severe heart failure. Heart. 1977;39:536-9. 
56. Rieg AD, Schroth SC, Grottke O, Hein M, Ackermann D, Rossaint R, et al. Influence of temperature on the positive inotropic effect of levosimendan, dobutamine and milrinone. Eur J Anaesthesiol. 2009;26:946-53.

57. Oung CM, English M, Chiu RC, Hinchey EJ. Effects of hypothermia on hemodynamic responses to dopamine and dobutamine. J Trauma. 1992;33:671-8.

58. Löllgen $\mathrm{H}$, Drexler $\mathrm{H}$. Use of inotropes in the critical care setting. Crit Care Med. 1990;18:556-60.

59. Contreras F. Dopamine, hypertension and obesity. Int Congr Ser. 2002;1237:99-107.

60. Mechem CC, Danzl DF. Accidental hypothermia in adults [Internet]. uptodate.com. 2012 [cited 2013 Feb 1]. Available from: http://www. uptodate.com/contents/accidental-hypothermia-in-adults?source=search result\&search=accidental +hypothermia\&selectedTitle=1\%7E150. Accessed 1 Dec 2016.

61. Nicodemus HF, Chaney RD, Herold R. Hemodynamic effects of inotropes during hypothermia and rapid rewarming. Crit Care Med. 1981;9:325-8.

62. Roscher R, Ingemansson R, Wetterberg T, Algotsson L, Sjöberg T, Steen S. Contradictory effects of dopamine at $32^{\circ} \mathrm{C}$ in pigs anesthetized with ketamine. Acta Anaesthesiol Scand. 1997:41:1213-7.

63. Filseth OM, How O-J, Kondratiev T, Gamst TM, Sager G, Tveita T. Changes in cardiovascular effects of dopamine in response to graded hypothermia in vivo*. Crit Care Med. 2012;40:178-86.

64. Filseth OM, Fredriksen K, Gamst TM, Gilbert M, Hesselberg N, Naesheim T. Veileder for håndtering av aksidentell hypotermi i Helse Nord. 2014. p. 1-19.

65. Polderman $\mathrm{KH}$. Of ions and temperature: the complicated interplay of temperature, fluids, and electrolytes on myocardial function. Crit Care. 2013;17:1018.

66. Pedersen TF, Thorbjørnsen ML, Klepstad P, Sunde K, Dale O. Therapeutic hypothermia-pharmacology and pathophysiology]. Tidsskr Nor Laegeforen. 2007;127:163-6.

67. Tortorici MA, Kochanek PM, Poloyac SM. Effects of hypothermia on drug disposition, metabolism, and response: a focus of hypothermia-mediated alterations on the cytochrome P450 enzyme system. Crit Care Med. 2007:35:2196-204.

68. Roizen MF, Weise V, Moss J, Kopin IJ. Plasma catecholamines: arterial-venous differences and the influence of body temperature. Life Sci Elsevier. 1975;16:1133-43.

69. Kelly LA, Wu C, Butcher RW. The escape of cyclic AMP from human diploid fibroblasts: general properties. J Cyclic Nucleotide Res. 1978;4:423-35.

70. Schaible N, Han Y-S, Hoang T, Arteaga GM, Tveita T, Sieck GC. Hypothermia/ rewarming disrupts excitation-contraction coupling in cardiomyocytes. Am Physiol Heart Circ Physiol. 2016;310:H1533-40.

71. Lewis ME, Al-Khalidi A-H, Townend JN, Coote J, Bonser RS. The effects of hypothermia on human left ventricular contractile function during cardiac surgery. J Am Coll Cardiol. 2002:39:102-8.

72. Eckmann DM, Bowers S, Stecker M, Cheung AT. Hematocrit, volume expander, temperature, and shear rate effects on blood viscosity. Surv Anesthesiol. 2001;45:252.

73. Dietrichs ES, Dietrichs E. Neuroprotective effects of hypothermia. Tidsskr Nor Laegeforen. 2015;135:1646-51.

74. Bernard SA, Gray TW, Buist MD, Jones BM, Silvester W, Gutteridge G, et al. Treatment of comatose survivors of out-of-hospital cardiac arrest with induced hypothermia. N Engl J Med. 2002;346:557-63.

75. Dietrichs ES, Kondratiev T, Tveita T. Milrinone ameliorates cardiac mechanical dysfunction after hypothermia in an intact rat model. Cryobiology. 2014;69:361-6.

76. Dietrichs ES, Håheim B, Kondratiev T, Sieck GC, Tveita T. Cardiovascular effects of levosimendan during rewarming from hypothermia in rat. Cryobiology. 2014;69:402-10.

77. Rungatscher A, Hallström S, Giacomazzi A, Linardi D, Milani E, Tessari M, et al. Role of calcium desensitization in the treatment of myocardial dysfunction after deep hypothermic circulatory arrest. Crit Care. 2013;17:R245.

78. Rungatscher A, Linardi D, Tessari M, Menon T, Luciani GB, Mazzucco A, et al. Levosimendan is superior to epinephrine in improving myocardial function after cardiopulmonary bypass with deep hypothermic circulatory arrest in rats. The journal of thoracic and cardiovascular surgery. J Thorac Cardiovasc Surg. 2012;143:209-14.

79. Tveita T, Sieck GC. Effects of milrinone on left ventricular cardiac function during cooling in an intact animal model. Cryobiology. 2012;65:27-32.

\section{Submit your next manuscript to BioMed Central and we will help you at every step:}

- We accept pre-submission inquiries

- Our selector tool helps you to find the most relevant journal

- We provide round the clock customer support

- Convenient online submission

- Thorough peer review

- Inclusion in PubMed and all major indexing services

- Maximum visibility for your research

Submit your manuscript at www.biomedcentral.com/submit
Biomed Central 